\title{
THE ROLE OF SEED BANKS IN THE PERSISTENCE OF ONTARIO'S COASTAL PLAIN FLORA ${ }^{1}$
}

\author{
P. A. Keddy And A. A. RezniceK \\ Department of Botany and Genetics, University of Guelph, Guelph, Ontario, Canada, N1G 2W1, \\ and University of Michigan Herbarium, Ann Arbor, Michigan 48109
}

\section{A B S T R A C T}

\begin{abstract}
Seed banks are important in wetland vegetation, but their role on lakeshores has received little attention. The influence of seed banks on lakeshore vegetation was investigated near eastern Georgian Bay in Ontario, where there is a rich shoreline and aquatic flora. Some lakeshore species found there can be considered "coastal plain disjuncts" similar to those of southwestern Michigan and adjacent Indiana, and central Wisconsin. Matchedash Lake in Simcoe Co., Ontario, has a particularly rich assemblage of these shoreline species. Based on short-term records, and aging of drowned stumps, we demonstrated that yearly mean water levels can and have changed by more than a meter. Such water-level fluctuations partly result from beaver dams on the single outlet stream. Vegetation data collected in a low-water phase (1976) document a rich shoreline flora, largely absent in the present (1979) high-water phase. During this latter high-water phase, we collected 15 sediment sample units from each of six water depths $(0-1.5 \mathrm{~m})$. The sample, representing $0.32 \mathrm{~m}^{2}$ of lake bottom, was planted out in a greenhouse; 3,149 seedlings representing 41 species of vascular plants emerged. Six (Rhexia virginica, Rhynchospora capitellata, Panicum spretum, Xyris difformis, Polygonum careyi, Linum striatum) are rare in Ontario. Estimated seed banks for individual species were as high as $6,500 \mathrm{seeds} \mathrm{m}^{-2}$. If another low-water phase occurs, a rich shoreline flora should again develop. We hypothesize that water-level fluctuations are essential to the long-term survival of these species.
\end{abstract}

CERTAIN AREAS in the Great Lakes region have long been known for their diverse herbaceous lakeshore and aquatic floras containing numerous rare species. Two areas of particular interest are southwestern Michigan and adjacent Indiana near the shore of Lake Michigan (Peattie, 1922, 1930; Voss, 1972) and central Wisconsin (McLaughlin, 1932). Peattie and McLaughlin considered these areas to be concentrations of disjunct Atlantic Coastal Plain species. Fernald (1942) criticized the careless use of this term, concluding that "the true members of the Atlantic Coastal Plain flora are rarely found off the coastal plain." Many of these Great Lakes species do occur prominently on the Atlantic Coastal Plain, however, and many of those now more widespread may well have persisted there during the Wisconsin glaciation. We will continue to use the term

\footnotetext{
${ }^{1}$ Received for publication 15 September 1980; revision accepted 9 March 1981.

We thank W. S. Benninghoff, director of the Matthaei Botanical Gardens of the University of Michigan for providing greenhouse facilities, and Carol Turner and Jan Keyes for their care of the seedlings. R. J. Hines of the Department of Mathematics and Statistics, University of Guelph, kindly advised us on aspects of the data analysis, and R. Proctor assisted with this analysis. P. M. Catling and D. W. Larson provided helpful criticism of a draft of the manuscript. This research was funded in part by NSERC Grant No. A6963.
}

coastal plain species in a broad sense to emphasize the geographic distributions of many of these species. Peattie $(1922,1930)$ stated that this floristic element entered the Great Lakes region not long after deglaciation, probably in association with the receding waterlines of post-glacial lakes.

Evidence has been accumulating that there is a third area in the Great Lakes region where such species are concentrated: the eastern and southeastern portion of the Georgian Bay region in Ontario (particularly eastern Parry Sound District, Muskoka District, and northern Simcoe County). Here there is a rich aquatic and shoreline flora rather similar to that of the above two regions. The map of Rhexia virginica in Soper (1956) provided an initial clue to the occurrence of this element. The recent discoveries of Bartonia paniculata subsp. paniculata (Reznicek and Whiting, 1976) Panicum spretum (Catling, Reznicek and Riley, 1977), Potamogeton bicupulatus (Reznicek and Bobbette, 1976), and Isoetes eatonii (Kott and Bobbette, 1980) add more species to the flora of this region, whose stations in the area are strikingly disjunct from the nearest colonies in the east. In spite of extensive examination of suitable shorelines, similar assemblages have not been found in other parts of Ontario. 
A particularly rich representation of shoreline species occurs on the shores of Matchedash Lake in Simcoe County. In addition to disjunct stations of Linum striatum, Panicum spretum, Potamogeton bicupulatus and Rhexia virginica, the shorelines support Bidens discoidea, Eleocharis olivacea, Fimbristylis autumnalis, Isoetes macrospora, Myriophyllum farwellii, Panicum sphaerocarpon, Polygonum careyi, Rhynchospora capitellata, and Xyris difformis. All of the above species are considered rare in Ontario (Argus and White, 1977). Other uncommon shoreline species include Carex cryptolepis, C. cumulata, Ceratophyllum echinatum, Muhlenbergia uniflora, Rhynchospora fusca, Utricularia purpurea, and $U$. resupinata. Although all of these species occur elsewhere in the eastern Georgian Bay area, and may be locally common, shoreline assemblages with this many rare species and such a large coastal plain component appear infrequent and localized. This raises a question with both biogeographic and ecological implications: why are these species so restricted in their occurrence? Or, more precisely, what are the ecological conditions associated with the presence of this flora, and why are these conditions apparently so uncommon in lakes?

There are three obvious ecological factors which influence among-lake variation in species composition.

1) Water chemistry: $\mathrm{pH}$ and conductivity have a marked influence on shoreline and aquatic species composition (e.g., Swindale and Curtis, 1957; Hutchinson, 1975; Crowder et al., 1977).

2) Geological history: large post-glacial lakes may have provided dispersal routes and much of the eastern Georgian Bay area was covered by post-glacial Lake Algonquin (Chapman, 1975). The geological history would also be reflected in substrate types and water chemistry.

3) Chance: lakes are isolated islands in a terrestrial ocean, and chance will play a role in dispersal, colonization and extinction of shoreline and aquatic plant species (Godwin, 1923; MacArthur and Wilson, 1967; Keddy, 1976).

The high species richness of Matchedash Lake was not easily attributed to any of these factors. The water chemistry and geological history of Matchedash Lake was not obviously different from nearby lakes, and it was improbable that chance alone would have produced such an exceptional assemblage. A fourth ecological factor was suggested by the abundance of many shoreline species during low-water phases of lakes. We hypothesized that year to year fluctuations in water level were associated with a rich shoreline flora and therefore with the long term survival of coastal plain species in Matchedash Lake. In this paper we ask the following two questions related to this hypothesis: 1) is there evidence of fluctuation in yearly mean water levels, in Matchedash Lake; and 2) if such fluctuations occur, how can these species survive unfavourable high-water conditions and reestablish during intervals with low-water levels?

MATERIALS AND METHODS-The study area-Matchedash Lake is situated on the boundary of Matchedash and North Orillia Twps, in Simcoe County, Ontario: (Lat. $44^{\circ} 47^{\prime}$, Long. $70^{\circ} 29^{\prime}$ ) at the extreme southern boundary of the Canadian Shield. It is a narrow lake $(4.5 \mathrm{~km}$ long by $0.3 \mathrm{~km}$ wide, on average) in a long shallow valley in precambrian granitic bedrock. There is a small drainage basin with no major inflowing streams. The shoreline is convoluted with numerous inlets and points. and there are scattered small islands. This area of Ontario was covered by post-glacial Lake Algonquin (Chapman, 1975). Potholes in the lakeshore rocks, revealed during low-water levels, are evidence that there was a great flow of water through this valley. Perhaps it was a former post-glacial drainage outlet of Lake Algonquin.

The vegetation and rock type place Matchedash Lake within the group of Ontario lakes characterized as "very soft, low conductivity lakes that are dominated by Isoetids and Utricularids" (Miller, 1977). The shoreline of the lake is largely rock and peat during high-water phases, but during low water there are long expanses of gravel, sand or peat forming gently-sloping shores. The surrounding upland vegetation is rocky barrens with Quercus rubra, $Q$. alba and Acer rubrum with scattered Pinus strobus.

Water-level fuctuations: data from submerged stumps-Only stumps still rooted in the bottom were selected for this work. Seven stumps could be found which were sufficiently intact to permit counting of growth rings; all had previously been cut off from 0.5 to $1 \mathrm{~m}$ above the ground. The oldest tree had a rotten centre; thus we could only estimate a minimum age. A measuring pole was used to estimate the number of $\mathrm{cm}$ of water covering the base of the stump.

Shoreline vegetation-The shoreline vegetation of Matchedash Lake had been examined 
in 1971 and at least once per annum from 1973 to 1979. During August 1976, one of us (Reznicek) collected quantitative data on the shoreline vegetation. During this low-water phase, Reznicek estimated the water line was $1.3 \mathrm{~m}$ below its present level. At each of eight locations around the lake, frequency data were collected at three levels (Fig. 1). The upper level was a band which had been entirely covered by water, but was exposed from 1973 to 1976. The middle level was covered by water up to 1975, but exposed in 1976. The low level was at the waterline or covered by water in 1976. Thus, the three shoreline levels had been exposed for 4,1 and 0 years respectively. At each location and each level, 10 quadrats of $1 \mathrm{~m}^{2}$ were examined. Each quadrat was separated by $4-5$ paces parallel to the water line. In collecting our sediment samples, we revisited three of these sites. Thus, for each of the three levels we knew the 1976 frequency of plant species in $n=30$ quadrats.

Sediment sampling procedure-A sample of sediment for seed germination studies was collected from six depths in Matchedash Lake on June 5 and 6, 1979. Three areas of lakeshore, each known to have had a rich shoreline flora from the 1976 data, were chosen for sediment sampling. At each of these three locations, we ran five transects from the shoreline to water $1.5 \mathrm{~m}$ deep. In each transect we took sediment from six water depths $(0,30,60,90,120$ and $150 \mathrm{~cm}$; see Fig. 1). At each depth in each transect, we took five sediment cores using a sampler with a diameter of $3 \mathrm{~cm}$; for each core the upper $5 \mathrm{~cm}$ was collected and the five cores from a given depth interval were combined. Thus, we had 15 transects with sample units from six depths, yielding 90 sample units $(6$ depths $\times 15$ transects); each sample unit was the sum of five sediment cores, representing $35 \mathrm{~cm}^{2}$ of lake bottom.

Germination from the sample was studied in the greenhouse at the University of Michigan's Matthaei Botanical Gardens. On 12 June 1979, each sample unit was spread evenly to a thickness of ca. $0.8 \mathrm{~cm}$ over the surface of a mixture of 2 parts fine sand, 2 parts ground Sphagnum peat and 1 part sterile potting soil (by volume) in a standard $54 \times 26 \times 6.5 \mathrm{~cm}$ tray. The tray was divided equally into six parts and one sample was placed in each part. The surface was kept continually moist with distilled water. Germination was evident within a few days. Seedling germination was recorded on the following dates: July 8, 16, 30; Aug. 10, 17, 23; Sept. 15, and Oct. 17. Virtually all the plants were identified by 17 October 1979. A

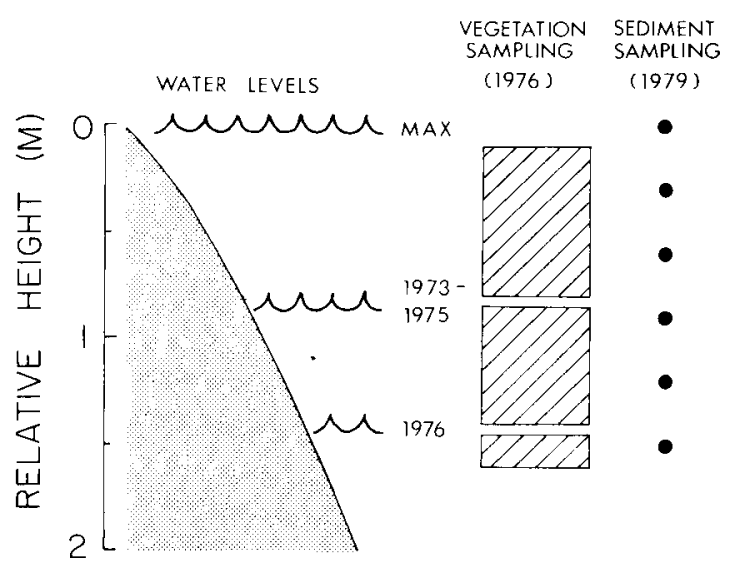

Fig. 1. Historic lake-level fuctuations and their position relative to vegetation sampling (1976) and sediment sampling (1979). Maximum water level refers to levels observed or inferred during 1968-1972 and 1977-1979.

few unidentified Cyperaceae and Compositae were grown to maturity and identified in 1980. The data consisted of a record of all species which germinated and survived to the age where they could be identified. Many seedlings (such as Rhexia virginica) could be identified with practice even from the cotyledons. To minimize mortality, larger individuals were removed as they were identified. Germination does not provide a complete assessment of the seed bank present (see Thompson and Grime, 1979), but it does illustrate seeds likely to germinate if lake levels fell and exposed the bottom.

Data analysis-Apart from demonstrating the actual presence of seeds in lake sediments, we wished to estimate the density of seeds in these sediments. Since each sample unit consisted of five samples from a 3-cm-diameter coring device, each sample unit represented $35 \mathrm{~cm}^{2}\left(5 \times 7 \mathrm{~cm}^{2}\right)$. Thus we multiplied by 286 to obtain estimates of the number of seeds $\mathrm{m}^{-2}$.

Testing whether the abundance of each species varied with depth presented problems. Since the sample units had been collected in transects of six depths, the sample units were related to an unknown degree. This invalidated any analysis of variance or related procedures which assume a random assignment of depths. Therefore, we used a nonparametric test which tests for differences between two matched samples (Siegel, 1956). To provide overall protection against a type-one error, a Bonferroni procedure (Miller, 1966) was used for each plant species, testing each pair of depths at a 0.003 level of significance for an overall level of at most 0.05 . Although this procedure is 
TABLE 1. Depth of water covering the bases of rooted stumps in 1979, and the estimated ages of the stumps

\begin{tabular}{ccc}
\hline \hline $\begin{array}{c}\text { Meters below } 1979 \\
\text { water level }\end{array}$ & $\begin{array}{c}\text { Estimated } \\
\text { age }(\mathrm{yr})\end{array}$ & $\begin{array}{c}\text { Diameter } \\
\text { (cm) }\end{array}$ \\
\hline 0.10 & $80+$ & 29 \\
0.25 & 80 & 29 \\
0.25 & 80 & 34 \\
0.35 & 65 & 36 \\
0.40 & 55 & 29 \\
0.50 & 40 & 22 \\
0.55 & 45 & 10 \\
\hline
\end{tabular}

conservative, the alternatives are complex and do not appear to be well established. We followed the methods of Siegel (1956) except that instead of dropping pairs of tied scores, we kept them in the analysis and assigned a positive or negative rank at random.

RESULTS-Water-level fluctuations-Evidence for the past water level fluctuations can be drawn from two sources: qualitative observations and the presence of rooted stumps well below the present high-water line. Regrettably, we know of no detailed historic record of water levels for Matchedash Lake.

Matchedash Lake itself is drained by a single outlet stream which flows out through a narrow rocky valley. During visits by Reznicek between 1968 and 1971 , water levels in the lake were high, being backed up by a beaver dam across the outlet stream. In 1973, the level of the lake had recently dropped about $80 \mathrm{~cm}$ lower than the previous years. In 1976, the beaver dam was gone, water levels had dropped about $50 \mathrm{~cm}$ farther, and water was just trickling out of the outlet stream. This stream had a bedrock base, so this appears to be a natural minimum level. (A gabion dam constructed by the Ministry of Natural Resources has returned water levels to approximately the 1968 to 1973 level.)

The presence of drowned stumps around the shoreline is additional evidence for previous low water levels. By aging Pinus strobus (white pine) stumps at any given depth it should be possible to determine when water levels were low enough to allow $P$. strobus seedlings to establish. Table 1 shows, for example, that there was a period of at least $40 \mathrm{yr}$ when water levels were low enough to permit the establishment and survival of white pine trees 0.5 $\mathrm{m}$ below the present high-water level. Similarly there were longer periods when water levels were apparently intermediate between these extremes.

Shoreline vegetation at the sample sitesDuring high-water phases, the shorelines of the
TABLE 2. Species composition of shoreline vegetation in August 1976 during a low-water phase. Three levels on the shore were examined. The table show's percent frequency for each species occurring in more than $5 \%$ of the quadrats $\left(\mathbf{n}=30\right.$ quadrats of $1 \mathrm{~m}^{2}$ for each of the levels). Refer to Fig. I for more details on sampling depths and water levels

\begin{tabular}{|c|c|c|c|}
\hline Species & $\begin{array}{c}\text { 4-yr-old } \\
\text { shoreline } \\
\text { (exposed } \\
\text { 1973) } \\
0.2-0.8 \mathrm{~m} \\
\text { below max } \\
\text { level }\end{array}$ & $\begin{array}{c}\text { 1-yr-old } \\
\text { shoreline } \\
\text { (exposed } \\
1976 \text { ) } \\
0.8-1.3 \mathrm{~m} \\
\text { below max } \\
\text { level }\end{array}$ & $\begin{array}{c}\text { Waterline } \\
\text { (not } \\
\text { exposed) } \\
1.3-1.5 \mathrm{~m} \\
\text { below max } \\
\text { level }\end{array}$ \\
\hline Drosera intermedia & 100 & 100 & - \\
\hline Viola lanceolata & 97 & 100 & 13 \\
\hline Rhynchospora capitellata & 97 & 87 & - \\
\hline Cladium mariscoides & 93 & - & - \\
\hline Panicum implicatum & 93 & 100 & - \\
\hline Rhexia virginica & 90 & 67 & - \\
\hline Calamagrostis canadensis & 80 & - & - \\
\hline Agrostis scabra & 70 & 50 & - \\
\hline Xyris difformis & 57 & 67 & - \\
\hline Lycopus unifforus & 50 & 33 & - \\
\hline Solidago graminifolia & 50 & 10 & - \\
\hline Muhlenbergia uniflora & 50 & 23 & - \\
\hline Hypericum canadense & 40 & 37 & - \\
\hline Bidens cernua & 40 & 77 & 7 \\
\hline Spiraea latifolia & 60 & 13 & - \\
\hline Rhynchospora fusca & 37 & 3 & - \\
\hline Juncus pelocarpus & 37 & 67 & 70 \\
\hline J. canadensis & 37 & 17 & - \\
\hline Lysimachia terrestris & 37 & + & - \\
\hline Triadenum fraseri & 30 & 3 & - \\
\hline Linum striatum & 30 & 30 & - \\
\hline Chamaedaphne calyculata & 27 & - & - \\
\hline Myrica gale & 27 & - & - \\
\hline Spiraea tomentosa & 23 & 7 & - \\
\hline Hypericum majus & 20 & 63 & - \\
\hline Panicum spretum & 20 & + & - \\
\hline Utricularia cornuta & 17 & 17 & 10 \\
\hline Polygonum careyi & 17 & 77 & - \\
\hline Comptonia peregrina & 13 & - & - \\
\hline Dulichium arundinaceum & 13 & 7 & - \\
\hline Agalinis paupercula & 13 & 7 & - \\
\hline Juncus effusus & 7 & - & - \\
\hline Pontederia cordata & + & 10 & 10 \\
\hline Glyceria canadensis & 7 & - & - \\
\hline Danthonia spicata & 7 & - & - \\
\hline Leersia oryzoides & 7 & 27 & - \\
\hline Carex lasiocarpa & 7 & 7 & - \\
\hline Eriocaulon septangulare & 3 & 100 & 100 \\
\hline Hypericum boreale & 3 & 57 & - \\
\hline Eleocharis acicularis & - & 20 & 13 \\
\hline Bidens tripartita & - & 17 & - \\
\hline Ludwigia palustris & - & 13 & + \\
\hline Myriophyllum tenellum & - & 7 & 60 \\
\hline Sagittaria graminea & - & 3 & 23 \\
\hline Utricularia resupinata & - & - & 13 \\
\hline
\end{tabular}

lake are dominated by shrubs such as Spiraea latifolia, Spiraea tomentosa, Myrica gale and Chamaedaphne calyculata, as well as dense stands of the grass Calamagrostis canadensis. Species such as Viola lanceolata, Rhexia virginica, Rhynchospora capitellata, Cladium mariscoides, and Panicum implicatum persist 


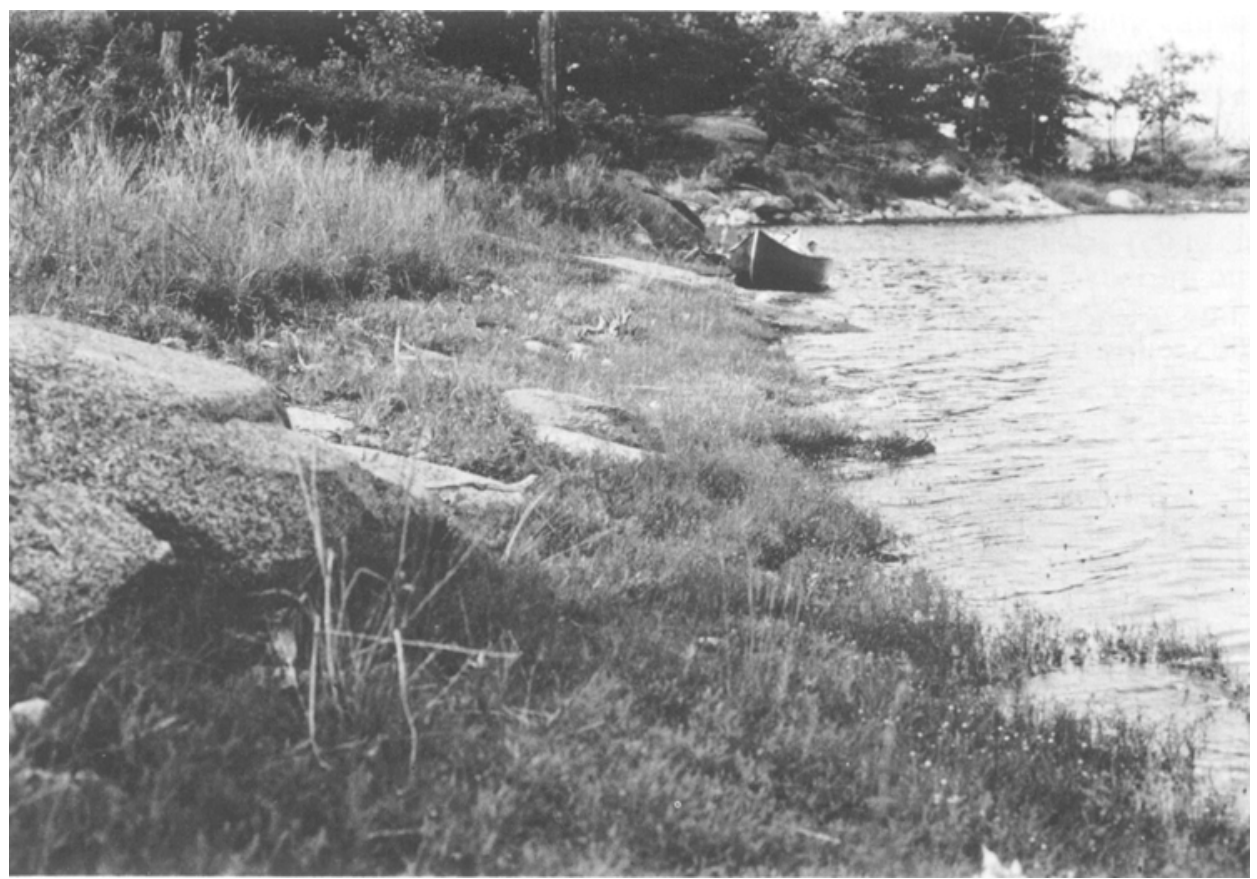

Fig. 2. Shoreline of Matchedash L. during 1976 low-water phase. Note gently sloping sandy shoreline. Species composition of this type of shore is given in Table 2. Shrubs and Calamagrostis canadensis are visible at upper left. Dense carpets of Eriocaulon septangulare (in flower) and Juncus pelocarpus are visible near the waterline at lower right.

as only widely-scattered individuals at the very fringe of the waterline. Other species such as Panicum spretum and Fimbristylis autumnalis may not be found at all.

Figure 2 shows a typical shoreline during the low-water phase of 1976 when vegetation data were collected. Table 2 shows species frequencies at three heights on the shoreline during this low-water phase. The upper shoreline (exposed $4 \mathrm{yr}$ ) was dominated by Calamagrostis canadensis and Cladium mariscoides with much Rhexia virginica, Rhynchospora capitellata, and locally, Linum striatum. The shrubs Spiraea latifolia and Chamaedaphne calyculata were also locally significant. The middle shoreline (exposed $1 \mathrm{yr}$ ) had a heavy dominance of Juncus pelocarpus and Viola lanceolata, with Panicum implicatum, Drosera intermedia, and Eriocaulon septangulare also important locally. The aquatic communities at these sites comprised beds of Eriocaulon septangulare and Juncus pelocarpus, with small areas of Myriophyllum tenellum and Sagittaria graminea. Included on these shores were all the other rare species of Matchedash Lake which were mentioned in the introduction. Table 2 also shows that shrubs such as Spiraea latifolia, S. tomentosa, Myrica gale, and Chamaedaphne calyculata, and the dense grass Calamagrostis canadensis were far more common on the upper shoreline than on the middle or lower one.

Seeds in bottom sediments-Figure 3 summarizes the germination results. The mean number of seedlings emerged (per sample unit) and the mean species richness (per sample unit) are plotted as a function of the depth at which the sediment samples were collected. Both the number of seedlings emerged and species richness peaked in samples collected from $60-90$ $\mathrm{cm}$ of water.

Table 3 shows the estimated densities of the 15 most abundant species which germinated from the sediment. Note that most occurred in their peak abundance in samples collected from 60 or $90 \mathrm{~cm}$ below the maximum water level. The last two columns give the density of germinating seedlings at the depth of peak abundance for that species. Thus for Hypericum majus, 913 seedlings germinated. The maximum number of seedlings came from those sample units taken from a depth of 60 $\mathrm{cm}$. At this depth, 22.9 seedlings per sample unit germinated, yielding an estimated density of 6,500 seeds $\mathrm{m}^{-2}$ of Hypericum majus at that depth. The $95 \%$ confidence intervals reveal that these are at best estimates of the order of magnitude of seed densities.

Figure 4 illustrates depth distributions in 


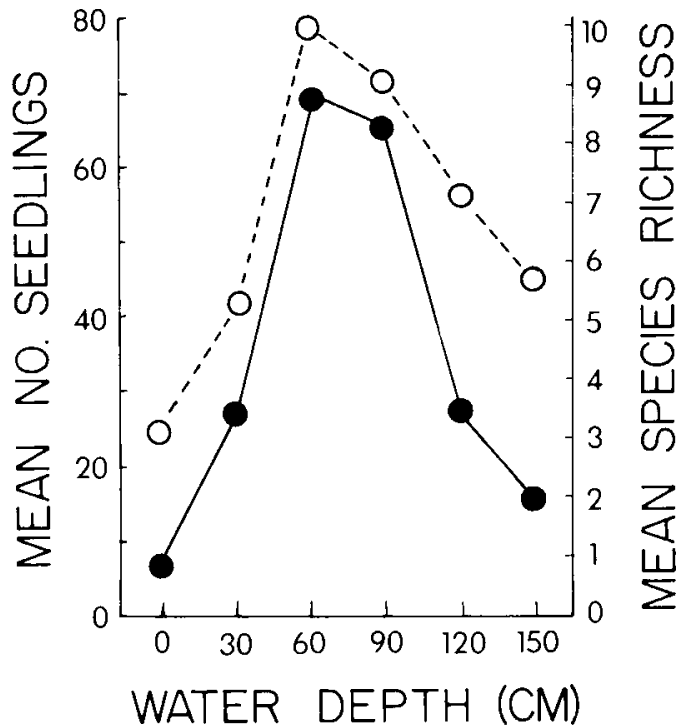

Fig. 3. The mean no. of seedlings emerged $\left(\mathrm{O}_{-}-\mathrm{O}^{-}\right)$ and mean species richness of the seedlings (- - - $)$ plotted against water depth from which sediment sample units were taken $(n=15)$ sample units for each depth).

more detail. For each of 12 species, the frequency (number of sample units which yielded seedlings) and density (mean number of seedlings recovered from each depth) are plotted against water depth. Most species had depth distributions which show significant differences among depths, with the peak density occurring in 60 to $90 \mathrm{~cm}$ of water.

Table 4 summarizes the abundance and depth distributions of the remaining 26 species,
TABLE 4. Seedlings germinated from Matchedash Lake sediments: species with between 3 and 30 occurrences $^{\mathbf{a}}$

\begin{tabular}{lccc}
\hline \hline \multicolumn{1}{c}{ Species } & $\begin{array}{c}\text { Total no. } \\
\text { seedlings }\end{array}$ & $\begin{array}{c}\text { Depth of } \\
\text { maximum } \\
\text { abundance }\end{array}$ & $\begin{array}{c}\text { No. } \\
\text { seedlings. } \\
\text { at that } \\
\text { depth }\end{array}$ \\
\hline Carex scoparia & 24 & 90 & 13 \\
Juncus pelocarpus & 19 & $60 / 90$ & 5 \\
Panicum spretum & 13 & 60 & 6 \\
Xyris difformis & 10 & 90 & 4 \\
Rhynchospora fusca & 7 & 60 & 3 \\
Ludwigia palustris & 7 & 90 & 4 \\
Carex lasiocarpa & 8 & 90 & 6 \\
Solidago graminifolia & 6 & 30 & 2 \\
Hypericum boreale & 6 & $60 / 120$ & 2 \\
Calamagrostis canadensis & 5 & 0 & 2 \\
Cladium mariscoides & 5 & 0 & 2 \\
Linum striatum & 4 & 90 & 2 \\
Polygonum persicaria & 3 & 90 & 3 \\
Gnaphalium uliginosum & 3 & & \\
Solidago rugosa & 3 & & \\
Lysimachia terrestris & 3 & 0 & 3 \\
\hline
\end{tabular}

a Also recorded were Carex echinata, Juncus dudleyi, Rubus arundelanus (2 seedlings each), and Bidens cernua, Drosera rotundifolia, Leersia oryzoides, Lycopus uniflorus, Triadenum fraseri, Chamaedaphne calyculata, and Carex buxbaumii (one seedling each).

all of which were represented by less than 30 germinating seedlings.

Discussion-Water levels in Matchedash Lake fluctuate from year to year. Given the single, small outlet stream for Matchedash Lake, the varying state of repair of a beaver dam could cause such fluctuations. Observa-

TABLE 3. Seedlings germinated from Matchedash Lake sediments: species with more than 30 occurrences. The mean number of seedlings and estimated seed bank columns are based only on the water depth at which the species nas most abundant

\begin{tabular}{lcccc}
\hline \hline \multicolumn{1}{c}{ Species } & $\begin{array}{c}\text { Total no. } \\
\text { seedlings }\end{array}$ & $\begin{array}{c}\text { Depth of } \\
\text { maximum } \\
\text { abundance }\end{array}$ & $\begin{array}{c}\text { Mean no. } \\
\text { seedlings } \\
\text { (per sample } \\
\text { unit) }\end{array}$ & $\begin{array}{c}\text { Estimated } \\
\text { seed bank } \\
\text { hundeds of } \\
\left.\text { seeds } \mathrm{m}^{-2}\right)^{\mathrm{a}}\end{array}$ \\
\hline Hypericum majus & 913 & 60 & $22.9(0.2-45.7)$ & $65(1-131)$ \\
Panicum implicatum & 398 & 60 & $11.0(3.2-18.9)$ & $31(9-54)$ \\
Viola lanceolata & 319 & 90 & $6.1(2.9-9.2)$ & $17(8-26)$ \\
Juncus effusus & 307 & 90 & $10.8(0-27.6)$ & $31(0-79)$ \\
Eriocaulon septangulare & 221 & 90 & $7.1(0.3-13.8)$ & $20(1-40)$ \\
Scirpus cyperinus & 150 & 60 & $5.3(0.4-10.2)$ & $15(1-29)$ \\
Agrostis scabra & 140 & 90 & $6.9(0-19.3)$ & $20(0-55)$ \\
Juncus canadensis & 139 & 60 & $2.3(0.7-3.9)$ & $7(2-11)$ \\
Muhlenbergia uniflora & 98 & 60 & $5.1(0-10.8)$ & $15(0-31)$ \\
Rhexia virginica & 75 & 60 & $3.1(0.8-5.5)$ & $9(2-16)$ \\
Spiraea latifolia & 54 & 120 & $1.7(0-3.5)$ & $5(0-10)$ \\
Hypericum canadense & 51 & 60 & $1.8(0-4.8)$ & $5(0-14)$ \\
Rhynchospora capitellata & 50 & 60 & $1.5(0.2-2.9)$ & $4(1-8)$ \\
Drosera intermedia & 44 & 60 & $1.9(0.1-3.6)$ & $5(0-10)$ \\
Polygonum careyi & 30 & 90 & $1.40(0-4.0)$ & $4(0-11)$ \\
\hline
\end{tabular}

a With $95 \%$ confidence interval. 
tions by Reznicek indicate that this has occurred. Longer term fluctuations might be related to variation in climate, or beaver food supplies. Table 1 may illustrate such a fluctuation. Thus, variation in water levels at Matchedash Lake could be the complex result of fluctuations from beaver activity superimposed on fluctuations resulting from variation in climate.

Data on species composition illustrate the richness of the shoreline floras on recently exposed shorelines during low-water phases. The abundance of shrubs and Calamagrostis canadensis on the 4-yr-old shoreline suggests a successional sequence, with aggressive species like these spreading to eventually dominate the exposed shoreline. Both Peattie (1922) and McLaughlin (1932) stated that coastal plain floras are crowded out by the development of more aggressive species. These data are consistent with their proposal, although soil characteristics (such as texture and moisture) also would be expected to vary with relative height.

Many of the species which grew during previous low-water levels are still present as seeds in the lake bottom sediments. Our germination studies illustrate that if water levels fell, an extremely rich shoreline flora would be expected to germinate. Table 3 showed that some species would germinate at maximum densities of hundreds or even thousands of seedlings $\mathrm{m}^{-2}$. The peak densities of seedling germination would occur between 60 and $90 \mathrm{~cm}$ below the present (maximum) lake level. Included in this new shoreline vegetation, based only on our seed bank data, would be six species considered by Argus and White (1977) to be rare in Ontario (Rhexia virginica, Rhynchospora capitellata, Panicum spretum, Xyris difformis, Polygonum careyi, and Linum striatum).

Comparison of Table 3 with Table 2 shows that the seed-pool results are similar to the vegetation present on the shores in 1976. The depth at which seedlings were most frequent in the seed-pool data was also often closely related to the position of the species during the previous low-water phase. There are, however, a few exceptions. Several species, notably Scirpus cyperinus, Juncus effusus, and $J$. canadensis, were apparently much more abundant in the seed pool than on the former lakeshore. All three of these species, however, were very abundant in swampy bays and inlets away from the sandy, gently sloping shores of the lake. It is possible that rising waters in the fall washed seeds out of these swampy areas and then dispersed the fine seeds around the lakeshore in a ring at the waterline. It is unknown whether such abundant dispersal of the species occurs naturally. It seems unlikely that beaver activity would normally cause rapidly rising water levels in the autumn; thus, these results may only reflect human intervention in the autumn construction of a gabion dam. Also, Agalinis paupercula was frequent in the 1976 data but was not noted in the seed pool. Perhaps the exacting germination requirements of this hemi-parasite were not met by our greenhouse conditions. With these exceptions, the seed bank was similar to the former community occupying the site, indicating a preponderance of seed deposition in situ, but differing slightly because of transportation of seeds of a few species from other communities.

Our original hypothesis was that water level fluctuations were associated with the rich shoreline flora of Matchedash Lake. We have demonstrated that there is evidence of fluctuations in lake water levels in both the long and short term. We have also demonstrated that the shoreline flora is rich during low-water phases, and that during high-water phases, large numbers of seeds remain viable on bottom sediments. Thus, we conclude that the rich shoreline flora on Matchedash Lake is intimately associated with fluctuations in water level. Moreover, we propose further that fluctuations in water level are actually essential for the survival of this flora. We hypothesize the following sequence of events. When water levels fall, a large expanse of habitat is opened up for herbaceous species, which germinate en masse from the seed bank. After several years of low water, shrubs and Calamagrostis canadensis begin invading the recently exposed lake bottom, crowding out the herbaceous component. Eventually water levels rise. The shrubs and $C$. canadensis are flooded out, and the herbaceous shoreline plants remain in the seed bank until the next low-water phase. Thus, many of the shoreline plants could be considered "fugitive species" (Harper, 1977) which survive only by repeatedly reoccupying temporarily exposed lake bottoms.

This hypothesized relationship between water-level fluctuations and a high species richness of shoreline plants is consistent with recent proposals on stability and diversity. The idea that stable environments support the most species has been challenged by Goodman (1975). Huston (1979) has proposed instead that environmental fluctuations enhance species diversity by preventing a few species from competitively excluding others. This would fit well with the observations of Peattie (1922) and McLaughlin (1932) that, in general, coastal plain species are gradually crowded out by more aggressive species.

While the role of seed banks may seem sur- 
Hypericum majus (913) Viola lanceolata (319) Panicum implicatum (398)
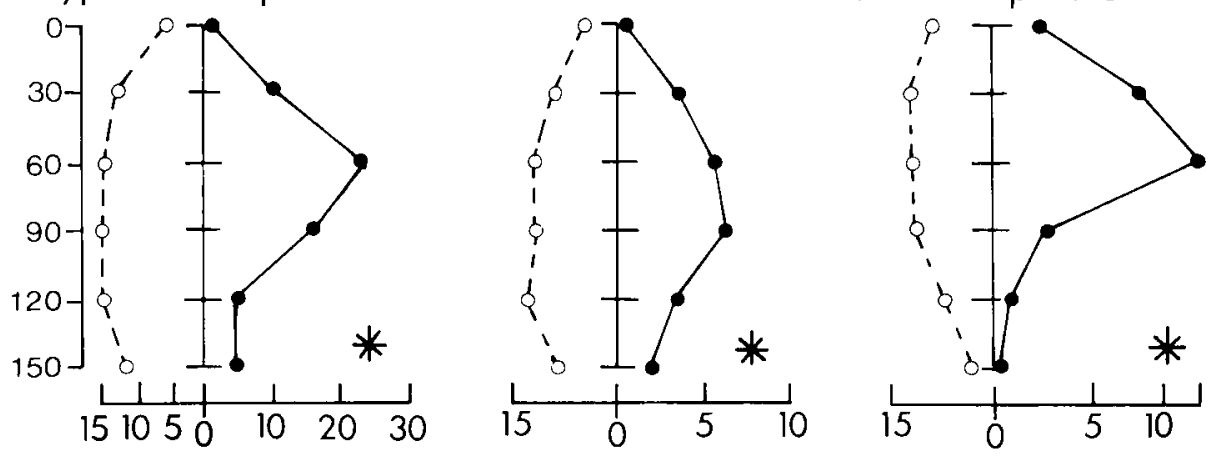

Juncus effusus (307) Eriocaulon septangulare (221)

Scirpus cyperinus (149)
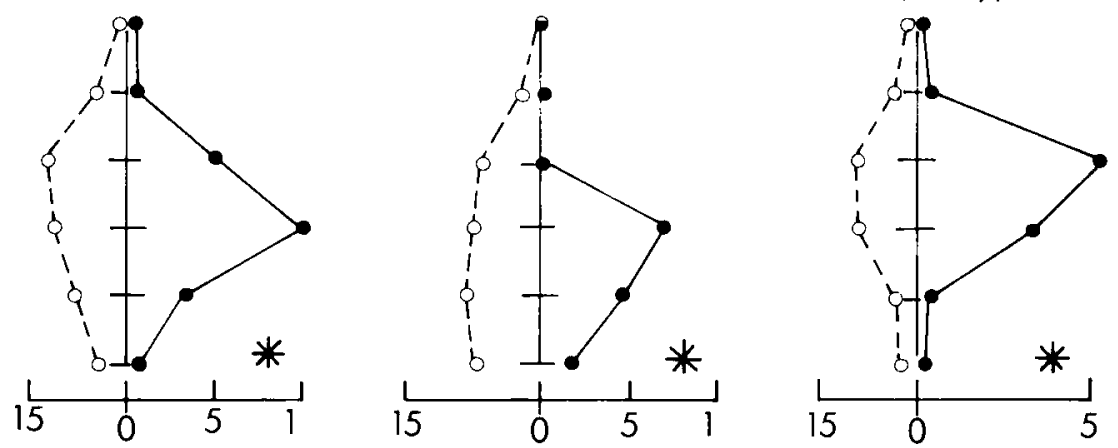

Juncus canadensis (139)

Agrostis scabra (140)

Muhlenbergia uniflora (98)
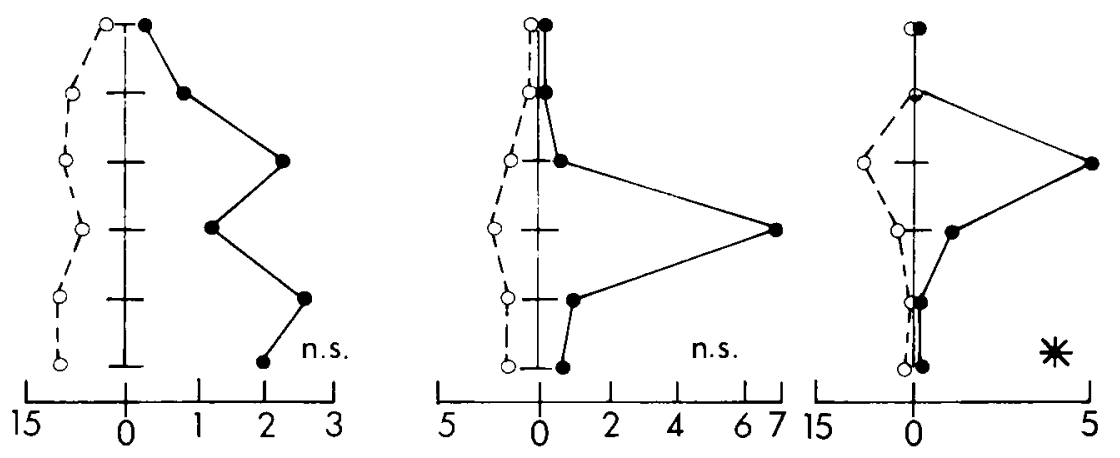

Rhexia virginica (75) Rhynchospora capitellata (50) Panicum spretum (13)
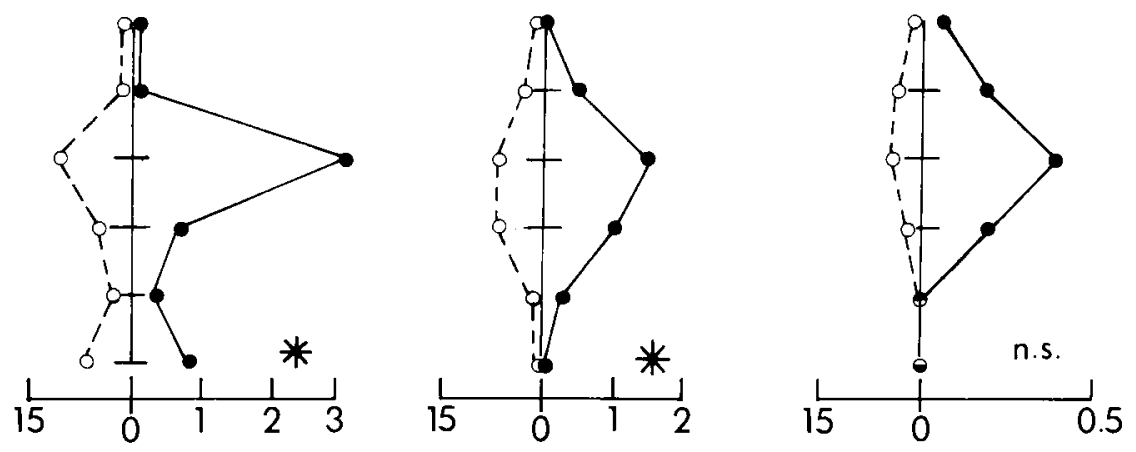
prising for a lakeshore flora, the importance of water-level fluctuations in marsh vegetation has been well documented, and drawdowns are a standard technique for managing marsh vegetation (Harris and Marshall, 1963; Van der Valk and Davis, 1978). Emergent vegetation reestablishes only during periodic low-water levels (Harris and Marshall, 1963). The large seed bank of such aquatic ecosystems has been well documented. Darwin (1859) reported that 537 seedlings germinated from nine tablespoons of mud he had collected from the shore of a small pond. More recently, Van der Valk and Davis $(1976,1978,1979)$ and Leck and Graveline (1979) have demonstrated the sizeable seed bank often found in marshes. Similarly, there are scattered reports of plant establishment from seeds buried in lakes (Billington, 1938; Salisbury, 1942). Salisbury notes ". . . the occasional presence on exposed mud of rare species in very large numbers . . . to disappear again for perhaps a quarter or half a century, is not merely evidence of the strikingly intermittent character of the conditions requisite for these species but also attests to the prolonged dormancy of the seeds."

The frequency of water-level fluctuations required to maintain a rich flora will be related to: 1) the length of time which seeds can survive on lake bottoms; and 2) their initial abundance. We know of no seed longevity data in any storage conditions for these species. It seems likely that low oxygen availability, low light, and cool temperatures are important considerations. Also, seed predation may be low. The abundance of seeds can be approximated using the conservative estimate of $7 \mathrm{~km}$ of shoreline around Matchedash Lake that had this well-developed shoreline flora in a band about $4 \mathrm{~m}$ wide. This yields, for example, 7 million seeds of Rhexia virginica, 1 million seeds of Panicum spretum, and 3 million seeds of Polygonum careyi. Although these are only orders of magnitude, these quantities of seeds would allow a relatively rapid rate of loss of viability through time without risk of extinction. Nevertheless, it is conceivable that relatively short periods without water level fluc- tuations might eliminate many species. Since the number of shorelines with a history of thousands of years of fluctuation is likely small, it is not surprising that lakes harboring a rich shoreline flora with a coastal plain floristic element are uncommon. This factor is especially critical with rare or disjunct species since, if they should become extinct in a lake, there may not be a seed source nearby.

Seed banks are not the only means of surviving high-water phases. P. M. Catling (pers. commun., 1980) noted that other species characteristic of lakeshores with fluctuating water levels survive high-water periods as vegetative individuals. Juncus pelocarpus and Utricularia resupinata are two such species which occur in Matchedash Lake. Gratiola aurea and Juncus militaris are other examples from lakes in the eastern Georgian Bay area. All of the above species flower and set seeds only in shallow water or when completely stranded.

From a management perspective, it is a serious disruption of these shorelines to build a dam which stabilizes water levels indefinitely. Neitiner, however, does this research justify turning such lakes into reservoirs. The combination of high-water years with lower-water years described above is not biologically equivalent to the daily or seasonal drawdowns characteristic of many reservoirs. The frequency and amplitude of fluctuations necessary for maximizing shoreline species richness remains a problem for future research.

Consider our original question: what are the ecological conditions which allow for the persistence of this rich shoreline flora, and why are they apparently so uncommon? We conclude that the persistence of this flora is in part accounted for by water level fluctuations, which periodically expose suitable habitat, and then re-flood it, eliminating shrubs and more aggressive shoreline plants. Most, if not all of these herbaceous shoreline species survive high-water phases in the seed bank on the lake bottom. Even if many other factors were suitable (e.g., soft water, gently sloping shores), for a lake to maintain a rich coastal plain flora, water-level fluctuations would have to occur continuously through time.

Fig. 4. Depth distributions of the nine most abundant species recorded in samples, and in bottom row, three rare species (Argus and White, 1977). Depth scale is at upper left. Plotted against depth are: 1) frequency-no. of sample units which yielded seedlings (to left of vertical axis); and 2) density-mean no. of seedlings recovered from each depth (to right of vertical axis). Note: horizontal scale for density varies among species. Number in brackets is the total no. of seedlings which germinated. Significance values were calculated as described in the methods. $(*=$ differences among depths are significant at the $P<0.05$ level.) 


\section{LITERATURE CITED}

Argus, G. W., AND D. J. White. 1977. The rare vascular plants of Ontario. Syllogeus Ser. 14, The National Museums of Canada, Ottawa.

Billington, C. 1938. The vegetation of Cranbrook Lake bottom. Cranbrook Inst. Sci. Bull. 11. Cranbrook Institute of Science, Bloomfield Hills, Mich.

Catling, P. M., A. A. Reznicek, and J. L. Riley. 1977. Some new and interesting grass records from southern Ontario. Can. Field Nat. 91: 350-359.

Chapman, L. J. 1975. The Physiography of the Georgian Bay-Ottawa Valley Area of Southern Ontario. Ont. Div. Mines, Geosci. Rep. 128.

Crowder, A. A., J. M. Bristow, M. R. King, and S. VANDERKLOET. 1977. The aquatic macrophytes of some lakes in southeastern Ontario. Nat. Can. 104: $457-464$.

DARWIN, C. 1859. The origin of species by means of natural selection or the preservation of favoured races in the struggle for life. (Mentor edition, the New American Library, 1958.)

FERNALD, M. L. 1942. Misinterpretation of Atlantic Coastal Plain species. Rhodora 44: 238-246.

GodwIN, H. 1923. Dispersal of pond floras. J. Ecol. 11: $160-164$.

Goodman, D. 1975. The theory of diversity-stability relationships in ecology. Q. Rev. Biol. 50: 237-266.

Harper, J. L. 1977. Population biology of plants. Academic Press, London.

Harris, S. W., and W. H. Marshall. 1963. Ecology of water-level manipulations on a northern marsh. Ecology 44: 331-343.

Huston, M. 1979. A general hypothesis of species diversity. Amer. Nat. 113:81-101.

Hutchinson, G. E. 1975. A treatise on limnology. Vol. III. Limnological Botany. John Wiley and Sons, New York.

KEDDY, P. A. 1976. Lakes as islands: the distributional ecology of two aquatic plants, Lemna minor $\mathrm{L}$. and L. trisulca L. Ecology 57: 353-359.

Kort, L. S., AND R. S. W. BobBetTE. 1980. Isoëtes eatonii, a quilwort new for Canada. Can. Field Nat. 94: 163-166.

Leck, M. A., ANd K. J. Graveline. 1979. The seed bank of a freshwater tidal marsh. Amer. J. Bot. 66: 1006-1015.

MacArthur, R. H., and E. O. Wilson. 1967. The theory of island biogeography. Princeton University Press, Princeton, N. J.
Mclaughlin, W. T. 1932. Atlantic coastal plain plants in the sand barrens of Wisconsin. Ecol. Monogr. 2: $335-383$.

Miller, G. E. 1977. A classification of Ontario lakes based on their submersed and floating macrophyte flora. M.Sc. thesis, University of Guelph, Guelph, Ontario.

Miller, R. G. 1966. Simultaneous statistical inference. McGraw-Hill, New York.

Peattie, D. C. 1922. The Atlantic coastal plain element in the flora of the Great Lakes. Rhodora 24: 57-70, $80-88$.

. 1930. Flora of the Indiana dunes. Field Museum of Natural History, Chicago.

ReZnicek, A. A., AND R. S. W. BobbetTe. 1976. The taxonomy of Potamogeton subsection hybridi in North America. Rhodora 78: 650-673.

—_- AND R. E. Whiting. 1976. Bartonia (Gentianaceae) in Ontario. Can. Field Nat. 90: 67-69.

Salisbury, E. J. 1942. The reproductive capacity of plants. G. Bell and Sons, London.

SIEGEL, S. 1956. Nonparametric statistics for the behavioral sciences. McGraw-Hill, New York.

SOPER, J. H. 1956. Some families of restricted range in the Carolinian flora of Canada. Trans. R. Can. Inst. XXXI, Part II: 69-90.

Swindale, D. N., and J. T. Curtis. 1957. Phytosociology of the larger submerged plants in Wisconsin lakes. Ecology 38: 397-407.

Thompson, K., ANd J. P. Grime. 1979. Seasonal variation in the seed banks of herbaceous species in ten contrasting habitats. J. Ecol. 67: 893-921.

VAN DER VALK, A. G., ANd C. B. Davis. 1976. The seed banks of prairie glacial marshes. Can. J. Bot. 54: 18321838 .

1978. The role of seed banks in the vegetation dynamics of prairie glacial marshes. Ecology 59: $322-335$.

- AND —. 1979. A reconstruction of the recent vegetational history of a prairie marsh, Eagle Lake. Iowa, from its seed bank. Aquat. Bot. 6: 29-51.

Voss, E. G. 1972. Michigan flora. A guide to the identification and occurrence of the native and naturalized seed-plants of the state, Part 1. Gymnosperms and monocots. Cranbrook Inst. Sci., Bull. 55. Cranbrook Institute of Science, Bloomfield Hills, Mich. and University of Michigan Herbarium, Ann Arbor. 